into employment of juveniles to the status of industrial relationship. At the same time, education authorities must face the realities of the economic world which the juvenile will enter or has recently entered. The day continuation school may become a real meeting-ground between the two worlds of education and industry if it is administered, not merely as an educational service, but also as a means of recovery and refreshment for the young worker. Until, however, the problem of entry into employment is tackled by all concerned as part of industry as a whole, all elaborations of the machinery of choice of employment and vocational guidance will be vain and its products largely a matter of hazard.

\section{HOUSEHOLD LIGHTING, HEATING AND VENTILATION}

PA APERS read at two of the series of twelve meetings of the Royal Society of Arts recently devoted to "The Post-War Home : Its Interior and Exterior", have now been published (J. Roy. Soc. Arts, June 26). R. Fitzmaurice, principal scientific officer at the Building Research Station of the Department of Scientific and Industrial Research, gave a lecture on the lighting, heating and ventilation of the ordinary house. Many facts of topical interest relating to domestic use of fuel and power were included. Nonfunctional design of working kitchens leads to needless waste of lighting. Plans are reproduced of the distribution of daylight in ill- and in well-designed kitchens using the same ground-plan with redistribution of the same areas of glass in the walls.

All three subjects are intimately related. Large window areas or windows opened for ventilation may lead to excessive use of fuel for heating. It is estimated that about half the total quantity of coal raised in Great Britain is used for providing warmth in buildings, the remaining half being used for power and heat in industry. Although Germany has a colder winter and maintains better heating conditions in buildings, the consumption of coal for heating per head of the population is considerably less than in Great Britain. Less use of open fires and increased use of smokeless fuel help economy. From a graph reproduced it is shown that in the last forty years the price of coal in London has more than doubled.

The very variable nature of the British climate is an obstacle to the use of some highly efficient heating systems. For example, in the United States, Germany and the U.S.S.R. centralized heating of a whole district from a single boiler house is practicable. It is well known that large plants need to work as nearly as possible to their capacity to obtain a high order of running efficiency. In Great Britain, however, an installation capable of handling the heating load during our relatively limited cold weather would not be running nearly to its capacity over the greater part of the heating season.

Contributions to the discussion included one by R. Grierson, of the Northmet Power Company, who gave details for the small house. The lowest amount spent per year for heating services-coke, coal, gas and electricity-is about £7-£8 a year. The ordinary clerk or member of the lower-paid professional classes spends $£ 15-£ 20$ per year. Mr. Grierson gave full details for his own house, where
$£ 28-£ 30$ a year is spent in heating its 12,000 cubic feet of space. For windows, a glass area of about 20 per cent of the floor area under normal conditions gives adequate natural lighting. A ratio of $12 \frac{1}{2}$ per cent makes a room definitely too dull.

The common type of German stove "is not a thing of beauty, but it does make for efficiency (45-70 per cent) and reduces the amount of heat energy lost up the chimney. If the Englishman gets 20 per cent of the heat energy of the coal into the room, that is to say, if he gets $12 s$. worth of heat out of $£ 3$ worth of coal, he is fortunate". In view of the national requirements in the economical use of fuel, these figures give food for thought.

A serious difficulty lies in the fact that the initial expense of the more efficient heating devices in a home is always greater than that of the inefficient. Similarly, a further wastage occurs in cheap roofing of houses. After the War of 1914-18, many cheap houses were built with roofs of tiles on laths. No lining of felt or other material under the tiles was used. As a result, the wind blows right through the loft space, the water in the cold storage tank is frozen in the cold weather, and the bedrooms are separated from an atmosphere which during last winter fell in temperature to $14^{\circ} \mathrm{F}$., by about three quarters of an inch of lath and plaster ceiling. Such roomssimilar conditions also occur in living-rooms in cheap bungalows-are in effect fitted with panelcooling; for it is found that on a hot day, if the temperature of the ceiling is only $10^{\circ} \mathrm{F}$. below that of the room, the cooling effect is most marked.

Mr. A. F. Dufton, also from the Building Research Station, found that a gas fire, designed to burn $0 \cdot 2$ therm an hour ( $5-8 \mathrm{kw}$.), had to be used for two hours in all in order to warm a room for half an hour for breakfast, so long as the walls remained in their original condition, consisting of plaster and wallpaper. When, however, the heat absorption of the walls was reduced by lining them with wood panelling, half an hour of previous heating instead of the original one and a half hours sufficed.

The eleventh lecture in the series was given by Miss Helen Masters, who dealt with equipment and maintenance in the kitchen. While the heat requirements for cooking are here again of great importance, many other factors are involved. The mere accumulation of labour-saving devices, without organization of the work to be done, will not promote efficieney. Architects have sometimes given so much attention to reducing the number of steps to be taken in walking from one part of the kitchen to another that they have designed kitchens which are too small to work in at all.

\section{SOUTH-EASTERN UNION OF SCIENTIFIC SOCIETIES}

\section{ANNUAL CONGRESS}

7 HE South-Eastern Union of Scientific Societies held its forty-seventh annual congress at Guildford on July 25, a single day of sessions and excursions attended by seventy representatives and members.

A representative assembly to transact the business of the seventy constituent societies was held in the County School for Girls, at which Dr. J. Ramsbottom, 
keeper of botany at the British Museum (Natural History) was elected president of the Union for 1942-43; in recent years he has served the Union as president of the Botanical Section. The new treasurer is Sir Gordon Hearn.

"Fungi and the Biology of Man" was the title of Dr. Ramsbottom's presidential address. He stated the facts concerning struggle and survival in fungi, the existence of races and their immutability, parasitism and symbiosis in outline: points of similarity and of contrast in man were indicated. Man does not inherit acquired characters in a biological sense, but he is heir to every other change. No pure races of man exist and the theory of race and blood is nonsense. Competition or struggle is universal, but in symbiosis an equilibrium has been attained. Competition in modern man is, for the most part, sociological and not biological. The State is an organization and not an organism. War between States is not a biological necessity nor is it transcendental. Man has his full complement of biological characters at birth : they are immutable. His ideas, his theories, his wishes are developed through culture : they can be changed and therein lie the hopes of civilization.

At the sectional sessions the following papers were read: "Historic London under Fire", by E. Yates, who exhibited the deplorable damage to medieval buildings caused by enemy action; "Studies in the Variation of Native Plants", by Dr. A. R. Clapham, who advocated co-operation by botanical societies for the proposed new Biological Flora of the British Isles (J. Brit. Ecol. Soc., 356; 1941) ; "Constructional Elements in the Physiography of the Southern Counties of England", by F. Owen Whitaker; "Spiders and their Life History and Habits", by E. A. Robins, who described a spider new to the British list, Marinda aurantia, the golden garden spider of America.

In the afternoon, Dr. W. St. Lawrence Finny, the retiring president, conducted a perambulation visiting and describing the history of St. Mary's Church, Guildford Castle and Museum, the Guildhall and its regalia and the Abbot's Hospital of 1619. Botanists visited the Compton district; geologists the Guildford brickworks and the Lower Greensand beds at Compton. It had been suggested that this Congress should be at Haslemere but, this being impracticable, the zoologists went there by train to see exhibits arranged in the Haslemere Educational Museum. There was a special exhibit of native flowers arranged by the Guildford Natural History Society, the officers of which organized local arrangements, and it was pleasing to see flowering specimens of our ancient woad, Isatis tinctoria L., now classed in most Floras as "a casual alien".

T. DANNREUTHER.

\section{THE ONTARIO RESEARCH FOUNDATION*}

\footnotetext{
THE report of the Ontario Research Foundation for the year 1941 includes the report of the Director, the audited financial statement and a list of publications issued to December 31, 1941. During the year the work of the Foundation has been increasingly concerned with problems associated directly

* Ontario Research Foundation. Report for the Year 1941. Pp. 25. (Ottawa, 1942.)
}

or indirectly with the War, and owing to the nature of much of the work in this field, as well as on problems of civilian production arising out of war-time restrictions on supplies of all kinds, a detailed reference to much of the work is not possible. The creation of centralized inspection laboratories has relieved the staff of much of the work in organizing and conducting laboratory work on behalf of the InspectorGeneral, but the securing and training for effective service of young graduates and technicians is a serious problem, although problems associated with personnel have been considerably reduced by the help of the local Registrar for Military Service. The quick and effective results which follow from full co-operation between men with long experience in industry and a scientific group actively engaged in research on the processes and materials of the industry have been demonstrated, and although it is clear that relations with industry require further development, the Director suggests that problems of the post-war period will afford a further opportunity for economical and effective work along these lines.

In the Department of Biochemistry, the Leather Laboratory has been used to varying extents by the Department of National Defence and the InspectorGeneral, and work on Service specifications has been continued in collaboration with the National Research Council. Preliminary tests have been made of a modified abrasion-testing machine for leather, and the production of organic acids from sugar by chemical and microbiological methods has continued. Methods for crude and refined lactic acid are now in use on a commercial scale in Toronto. A good deal of time has been devoted to a careful comparison of chemical and microbiological methods for determining the vitamin $B_{1}$ content of foodstuffs, including bread. In the Department of Agriculture, the Pathological Laboratory has investigated the infection of small experimental animals with Ascaris lumbricoides, and the same Department has now completed the greater part of its field work on the climate and main soil types of southern Ontario, and in co-operation with the Federal Department of Entomology has made a rapid survey of southern Ontario to determine the location and extent of nematode infection in oats.

In the Textile Department a reasonable balance has been maintained between testing, short-term problems and more fundamental research, and an investigation has been undertaken on the treatment of various synthetic fibres to overcome the serious drawback that they cannot be given a high degree of twist in their natural state without serious troubles developing in the knitting operation, and encouraging results have been obtained in collaboration with the Dominion Silk Mills, Ltd. Partly successful attempts have been made to obtain new products for processing wools from raw materials which are and will be available in Canada.

In the Department of Chemistry, the organic and metallurgical analytical laboratories have continued to operate on behalf of the Inspector-General and there has been a marked increase in the number of problems submitted by outside firms. The Gas Laboratory has given several months to the study of steaming of horizontal retorts at one of the plants of the Consumers' Gas Company, and in the Department of Metallurgy gauge-testing, heat-treatment, physical testing and metallography services have been available to Government departments and manufacturers, and the long-term research programme has largely been brought to a standstill. 